\title{
Review
}

\section{Mechanism-based medication development for the treatment of nicotine dependence}

\author{
Zheng-xiong XI*, Krista SPILLER, Eliot L GARDNER \\ Intramural Research Program, National Institute on Drug Abuse, National Institutes of Health, Baltimore, MD 21224, USA
}

Tobacco use is a global problem with serious health consequences. Though some treatment options exist, there remains a great need for new effective pharmacotherapies to aid smokers in maintaining long-term abstinence. In the present article, we first discuss the neural mechanisms underlying nicotine reward, and then review various mechanism-based pharmacological agents for the treatment of nicotine dependence. An oversimplified hypothesis of addiction to tobacco is that nicotine is the major addictive component of tobacco. Nicotine binds to a $4 \beta 2$ and a7 nicotinic acetylcholine receptors (nAChRs) located on dopaminergic, glutamatergic and GABAergic neurons in the mesolimbic dopamine (DA) system, which causes an increase in extracellular DA in the nucleus accumbens (NAc). That increase in DA reinforces tobacco use, particularly during the acquisition phase. Enhanced glutamate transmission to DA neurons in the ventral tegmental area appears to play an important role in this process. In addition, chronic nicotine treatment increases endocannabinoid levels in the mesolimbic DA system, which indirectly modulates NAc DA release and nicotine reward. Accordingly, pharmacological agents that target brain acetylcholine, DA, glutamate, GABA, or endocannabonoid signaling systems have been proposed to interrupt nicotine action. Furthermore, pharmacokinetic strategies that alter plasma nicotine availability, metabolism and clearance also significantly alter nicotine's action in the brain. Progress using these pharmacodynamic and pharmacokinetic agents is reviewed. For drugs in each category, we discuss the mechanistic rationale for their potential anti-nicotine efficacy, major findings in preclinical and clinical studies, and future research directions.

Keywords: nicotine; reward; addiction; smoking cessation

Acta Pharmacologica Sinica (2009) 30: 723-739; doi: 10.1038/aps.2009.46; published online 11 May 2009

\section{Introduction}

Nicotine use and dependence is a world-wide health problem. In the United States alone, approximately 45 million people smoke cigarettes and the adverse health effects from cigarette smoking account for an estimated half million deaths each year ${ }^{[1]}$. Though many cigarette smokers report a desire to quit smoking, few are successful. In fact, according to the US Department of Health and Human Services, approximately $80 \%$ of smokers who attempt to quit relapse before achieving 6 months of abstinence. Of the remainder, relapses may occur years after a smoker initially quits ${ }^{[2]}$. Consequently, there is a great need for pharmacotherapies to aid smokers who wish to quit.

Although the mechanisms underlying tobacco addic-

* Correspondence to Dr Zheng-xiong XI.

E-mail zxi@mail.nih.gov

Received 2009-02-14 Accepted 2009-03-24 tion are not completely understood, accumulating evidence indicates that nicotine is the major addictive component ${ }^{[3,4]}$. In preclinical experimental conditions, nicotine produces many hallmark behaviors observed with other addictive drugs. Non-contingent administration of nicotine stimulates locomotor activity ${ }^{[5,6]}$ and enhances electrical brainstimulation reward $^{[7]}$. It can also reinforce intravenous selfadministration ${ }^{[3,8]}$, produce conditioned place preference ${ }^{[9]}$, and serve as a discriminative stimulus in animals ${ }^{[10]}$. In addition, nicotine cessation produces withdrawal syndromes with both somatic and affective symptoms ${ }^{[4,11]}$, and those symptoms can be alleviated by nicotine replacement.

\section{Neural mechanisms underlying nicotine dependence}

Nicotinic acetylcholine receptors (nAChRs) Nicotine is an alkaloid that binds to central and peripheral nicotinic acetylcholine receptors (nAChRs). Acetylcholine (ACh) is 
an endogenous neurotransmitter that binds to and activates nAChRs. Neuronal nAChRs are ligand-gated ion channels with high permeability to $\mathrm{Ca}^{++}$, and are formed from combinations of five subunits ${ }^{[12,13]}$. To date, twelve different neuronal $\mathrm{nAChR}$ subunits have been cloned, including nine $\alpha$-subunits $(\alpha 2-\alpha 10)$ and three $\beta$-subunits $(\beta 2-\beta 4)$. Non-neuronal subunits, $\alpha 1, \beta 1, \gamma, \delta$, and $\varepsilon$, form peripheral nicotinic receptors at the neuromuscular junction ${ }^{[14]}$. The neuronal subunits combine with a stoichiometry of two $\alpha$ and three $\beta$-, or five $\alpha 7$-subunits to form nAChRs ${ }^{[15]}$. Both the $\alpha 4 \beta 2$ and $\alpha 7$ subtypes of nAChRs are the most abundant subtypes in the brain and are localized on presynaptic terminals, axons, somatodendrites or on postsynaptic cells ${ }^{[16,17]}$. Overall, activation of presynaptic nAChRs by ACh or nicotine potentiates neurotransmitter release, while activation of postsynaptic nAChRs increases excitability of postsynaptic cells by increasing $\mathrm{Ca}^{++}$influx via $\mathrm{nAChR}$ channels.

ACh-glutamate-GABA-DA mechanisms underlying nicotine dependence Although many areas of the brain are involved in reward, the mesocorticolimbic dopamine (DA) system serves a vital and fundamental role in mediating the rewarding and psychostimulant effects of addictive drugs, including nicotine ${ }^{[9,18]}$. This system originates from DA neurons in the ventral tegmental area (VTA) in the midbrain and projects to the nucleus accumbens (NAc), the amygdala and the prefrontal cortex ${ }^{[18]}$. The activity of VTA DA neurons is regulated by excitatory glutamatergic inputs predominantly from the prefrontal cortex, cholinergic inputs from brainstem nuclei and inhibitory GABAergic inputs within the VTA or from the NAc (Figure 1). This DA model is supported by a number of findings ${ }^{[9,19]}$. For example, nicotine self-administration elevates NAc DA, and that elevation reinforces nicotine self-administration, particularly during the acquisition phase ${ }^{[20]}$. In contrast, chemical lesion of DA terminals or pharmacological blockade of DA receptors in the NAc attenuates the rewarding effects of nicotine, as indicated by reduced self-administration ${ }^{[8,21]}$.

Several studies suggest that the $\alpha 4 \beta 2 \mathrm{nAChR}$ subtype plays a major role in nicotine reward. First, pretreatment with the selective $\alpha 4 \beta 2$ receptor antagonist dihydro- $\beta$ erythroidine (DH $\beta E)$ or the partial agonist SSR591813 significantly inhibits nicotine self-administration in rats ${ }^{[22,23]}$. Similarly, genetic deletion of $\beta 2$ subunits abolishes nicotine self-administration ${ }^{[24]}$. Second, in vivo microdialysis studies indicate that the selective $\alpha 4 \beta 2$ receptor partial agonist SSR591813 or genetic deletion of $\alpha 4$ or $\beta 2$ subunits prevents nicotine-induced increase in NAc $\mathrm{DA}^{[23-25]}$. Third, nicotinemediated currents from VTA neurons are inhibited by $\mathrm{DH} \beta \mathrm{E}^{[24,26-28]}$ or dramatically decreased on midbrain neu- rons in $\beta 2$-null mice ${ }^{[24,28]}$. Fourth, brain slices from $\alpha 4$ - or $\beta 2$-subunit knockout mice lack high-affinity nicotine binding, confirming that most (if not all) binding sites for nicotine in adult brains contain $\alpha 4 \beta 2$-containing receptors ${ }^{[24,29]}$. These data suggest that both $\alpha 4$ and $\beta 2$ subunits in the VTA are crucial in mediating nicotine's DA-releasing effects. Thus, the effects of nicotine on DA function could be mediated by activation of $\alpha 4 \beta 2 \mathrm{nAChRs}$ located on DA neurons in the VTA and on DA terminals in the NAc ${ }^{[30]}$.

In addition, several studies suggest the involvement of other nAChR subunits, including $\alpha 3, \alpha 6, \alpha 7$, and $\beta 3$, in the control of DA release induced by nicotine. It was reported a $7 \mathrm{nAChRs}$ are also expressed on VTA DA neurons ${ }^{[31,32]}$, and nicotine still activates midbrain neurons in $\beta 2$-subunit knockout mice by a $\alpha 7-\mathrm{nAChR}$ mediated mechanism ${ }^{[28]}$, suggesting the involvement of $\alpha 7 \mathrm{nAChRs}$ in nicotine's action. Differential distribution of $\mathrm{nAChR}$ subtypes has been found on glutamatergic $(\alpha 7)$ and GABAergic $(\alpha 4 \beta 2)$ terminals in the VTA ${ }^{[27,28,33]}$. Different $n A C h R$ subtypes appear to show different levels of desensitization: the $\alpha 4 \beta 2$ subtype desensitizes more rapidly than the $\alpha 7$ subtype $^{[32]}$. Therefore, it has been proposed that nicotine first activates then desensitizes $\alpha 4 \beta 2$ nAChRs on VTA DA neurons, producing an initial fast increase in extracellular DA in the $\mathrm{NAc}^{[12,24,26]}$. At the same time, nicotine also excites $\alpha 7 \mathrm{nAChRs}$ located on presynaptic glutamatergic terminals and increases excitatory glutamatergic inputs to VTA DA neurons. Since the $\alpha 7 \mathrm{nAChRs}$ have much lower affinity for nicotine than $\alpha 4 \beta 2 \mathrm{nAChRs}$, and are therefore much less susceptible to desensitization by low concentrations of nicotine obtained from tobacco smoking, the enhanced glutamate release causes prolonged DA neuron activation ${ }^{[34]}$. In addition, nicotine may also excite $\alpha 4 \beta 2$ receptors located on VTA GABAergic neurons to increase GABA release ${ }^{[35]}$. Thus, the DA-releasing effects of nicotine may result from a modification of the balance between excitatory and inhibitory inputs to DA neurons ${ }^{[12,26,36]}$. This hypothesis may in part explain the finding with in vivo microdialysis that a single injection of nicotine produces long-term $(2 \mathrm{~h})$ increases in extracellular NAc DA ${ }^{[9]}$.

It should be pointed out that not all evidence supports this hypothesis. For example, conflicting findings were found in mutant mice lacking the $\alpha 7$ receptors or in rats injected with the relatively selective $\alpha 7 \mathrm{nAChR}$ antagonist methyllycaconitine ${ }^{[37,38]}$. Although much attention has focused on the VTA-NAc pathway, many other brain sites that are not yet extensively studied are also likely to contribute to nicotine reward and addiction.

Chronic nicotine-induced neuroadaptations Most smokers report that the first cigarette of the day produces the 


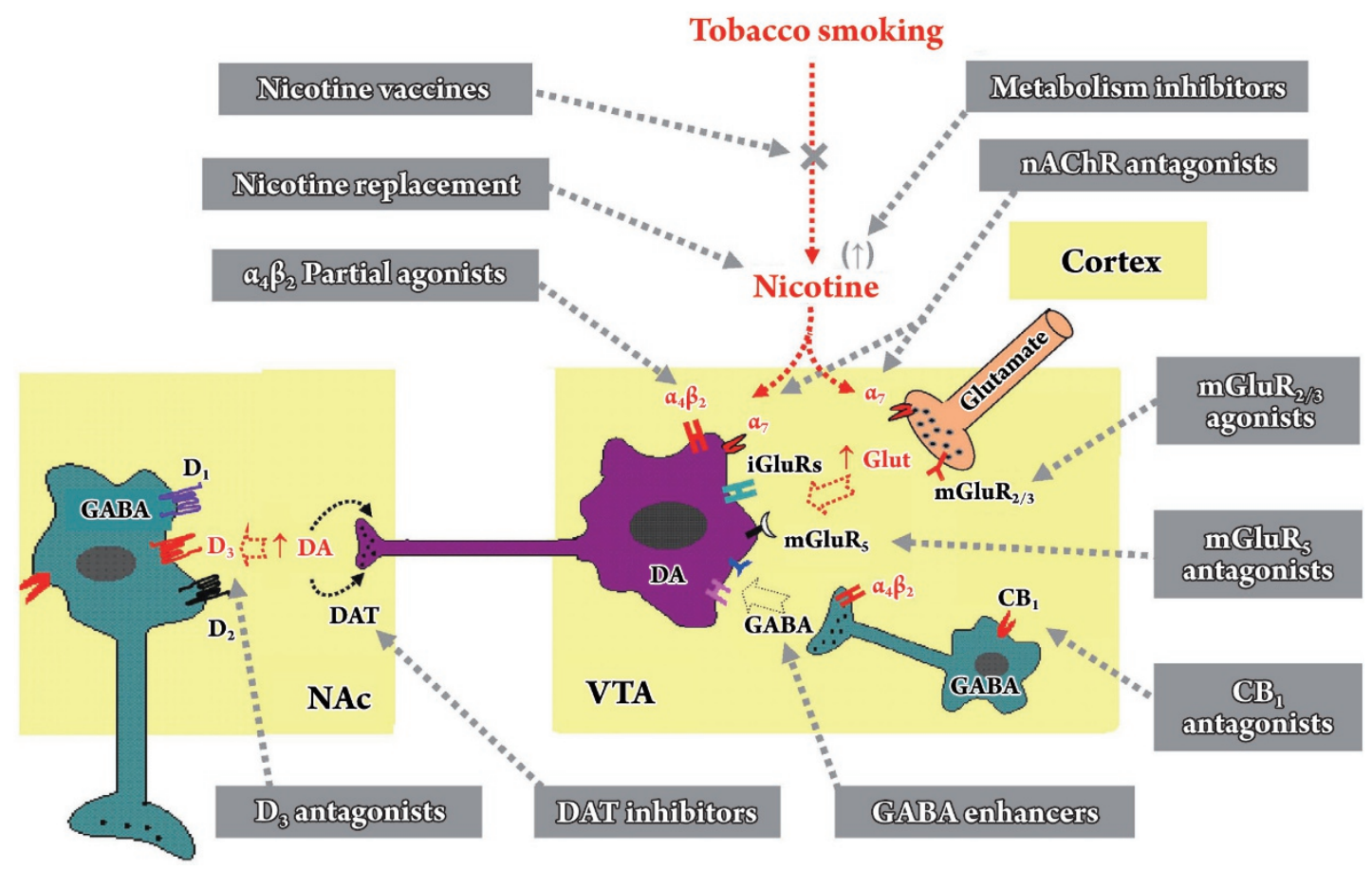

Figure 1. Schematic diagram of the mesolimbic dopamine (DA) projection pathway, illustrating the actions of nicotine on extracellular DA, glutamate and GABA in the ventral tegmental area (VTA), and the sites of action of various mechanism-based pharmacological agents in medication development for the treatment of tobacco dependence. The mesolimbic DA system originates in the VTA and projects to the nucleus accumbens (NAc). In the VTA, DA neurons (purple) are under tonic excitatory glutamatergic afferent influence from the medial prefrontal cortex (orange), and tonic inhibitory GABAergic afferent influence from GABAergic interneurons (teal) and also from long-loop GABAergic projections from the NAc (not shown). Nicotine activates mesolimbic DA neurons either via $\alpha_{4} \beta_{2}$ nAChRs located on VTA DA and GABAergic neurons or via $\alpha_{7} \mathrm{nAChRs}$ on DA neurons and glutamatergic terminals. Chronic nicotine exposure may also increase endocannabinoid contents in the VTA and NAc, which may remove the tonic inhibitory GABAergic control on VTA DA neurons via $\mathrm{CB}_{1}$ receptors localized on VTA GABAergic neurons or their terminals. Based on this hypothesis, various pharmacological agents that target ACh, DA, glutamate, GABA, and endocannabinoid transmission have been proposed and studied for their potential use in the treatment of tobacco dependence. More details for each class of pharmacological agents are discussed in the text of this review.

most powerful effects ${ }^{[39]}$, suggesting that fast tolerance and desensitization develop after repeated exposure to nicotine. This could be related to findings that chronic exposure to nicotine results in fast desensitization of $\alpha 4 \beta 2 \mathrm{nAChRs}$, leading to upregulation of $\alpha 4 \beta 2 \mathrm{nAChRs}$ on the cell surface ${ }^{[12,28,40-42]}$. On the other hand, repeated administration of nicotine is also associated with sensitization, an effect that appears to be mediated (at least with respect to locomotor sensitization) by $\alpha 4 \beta 2$ subunits $^{[23,43]}$. Sensitization of the motivational effects of nicotine is also seen in the self-administration and conditioned place preference paradigms ${ }^{[44,45]}$. These neuroadaptations may contribute to the development of nicotine $\operatorname{addiction}^{[36]}$.

\section{Animal models of nicotine dependence}

Animal models of addiction are, by definition, approxi- mations of human drug abuse. A major obstacle to the development of medication for nicotine dependence is the lack of animal models with sufficient predictive clinical validity, and therefore, multiple animal models have to be used to emulate different aspects of nicotine dependence in humans. Six behavioral animal models or measures have been widely used in research on nicotine dependence.

Self-Administration Drug self-administration reliably models drug reinforcement ${ }^{[46]}$. In this model, laboratory animals are allowed to operantly self-administer addictive drugs, such as nicotine. Two commonly used self-administration paradigms are fixed-ratio (FR) and progressive-ratio (PR) schedules of drug reinforcement. In the FR paradigm, a drug infusion follows after a fixed number of responses by the animal, eg, after every one (FR1) or two (FR2) lever presses. In the PR reinforcement paradigm, a progressively increasing work-load (eg, lever pressing) is imposed upon the animal in 
order to receive one drug administration. Eventually, a point is reached at which the animal stops responding. This is termed the PR "break-point" and is considered a measure of rewarding efficacy ${ }^{[47]}$.

Reinstatement of drug-seeking behavior Nicotine dependence is characterized by high rates of relapse to tobacco use. The reinstatement animal model is widely used to model relapse to tobacco use in humans ${ }^{[48]}$. In this model, rats are implanted with intravenous catheters and are allowed to self-administer nicotine until stable nicotine-taking is achieved. Then, vehicle is substituted for nicotine. Since the animals are no longer rewarded, they stop ("extinguish") the nicotine-seeking behavior. Next, the experimenter administers a stimulus to "trigger" the animal to relapse — to go back to the drug-seeking behavior that previously resulted in intravenous infusions of nicotine. Three triggers cause relapse in this model: 1) re-exposure to nicotine, 2) re-exposure to environmental cues that were previously associated with nicotine self-administration, or 3) exposure to mild stress. The face validity of the reinstatement models rest upon the fact that these are the triggers that provoke relapse to tobacco use in humans ${ }^{[46]}$.

Conditioned Place Preference (CPP) The CPP model is an experimental procedure to study the rewarding effects of nicotine and/or reward-related learning and memory. In this model, a distinctive environment (in wall color, light, floor texture) in one compartment of a two- or threecompartment apparatus is paired repeatedly with nicotine or vehicle injections. CPP occurs when repeated nicotine administration in one particular environment results in the ability of previously neutral environmental stimuli to elicit approach behavior and increased time spent in that environment even in the absence of nicotine administration. It has been argued that CPP, like self-administration and several other behavioral measures, is an example of DA-mediated incentive learning and memory, and that the approach behavior and increased time spent by animals in nicotinepaired environment can be considered a measure of nicotineseeking behavior ${ }^{[49]}$.

Drug discrimination Drug discrimination procedures are often used as animal models for the subjective effects of an addictive drug ${ }^{[46]}$. The animal is trained to make one response when nicotine is given and a different response when vehicle is given. Well-trained animals typically make close to $100 \%$ appropriate responses to discriminate nicotine from vehicle. The degree to which a novel drug is perceived by the animal as "nicotine-like" versus "not-nicotine-like" is reflected in the percentage of nicotine-associated responses versus vehicle-associated responses. By combining a novel drug (eg, a putative anti-nicotine therapeutic agent) with nicotine in this paradigm, one can determine the degree to which the novel drug increases or decreases the subjective "nicotine-like" feeling experienced by the animal.

Brain stimulation reward Virtually all addictive drugs not only have rewarding actions of their own, but also potentiate the rewarding actions of other substances or events ${ }^{[50]}$. The brain stimulation reward (BSR) paradigm models this property of addictive drugs by directly assessing the degree of drug-induced enhancement of BSR in animals trained to respond for electrical stimulation of specific brain-reward loci such as the VTA, medial forebrain bundle, or NAc. To assess drug-induced enhancement of BSR, the "rate-frequency curve-shift" paradigm is commonly used to measure changes in BSR thresholds after drug administration. Addictive drugs (such as nicotine) produce highly characteristic leftward shifts (eg, decreased BSR threshold) in these functions, indicating summation between the reward provided by the electrical stimulation and the drug-induced reward. This paradigm is therefore useful in the search for compounds with potential anti-addictive therapeutic properties and, conversely, to screen compounds for reward-enhancing properties, which might be predictive of intrinsic addictive potential $^{[46]}$.

Withdrawal Many tobacco smokers report that they experience unpleasant withdrawal symptoms when they quickly quit smoking. In experimental animals, abrupt cessation of chronic nicotine or administration of $\mathrm{nAChR}$ antagonists causes somatic withdrawal symptoms, such as shakes/ tremors, gasps/writhes, teeth chattering and ptosis ${ }^{[51,52]}$, which may in part mimic withdrawal symptoms experienced by abstinent smokers ${ }^{[53]}$. In addition, nicotine withdrawal also results in reduced DA overflow in the NAc ${ }^{[54]}$ and elicits changes in behavior that are characteristic of anhedonia ${ }^{[11]}$. BSR, described above, can also be used to measure nicotine withdrawal-induced anhedonia ${ }^{[36,46]}$. These changes are thought to model the dysphoria experienced by many smokers when they first quit ${ }^{[55]}$. Strikingly, all these symptoms can be reversed by nicotine replacement therapy ${ }^{[11]}$. Thus, relieving nicotine withdrawal symptoms, thought to be an important reason for relapse to tobacco use, may be another strategy to aid cessation of tobacco smoking.

\section{Mechanism-based medication discovery}

Although several types of pharmacological therapies have been approved for smoking cessation in both North America and Europe, long-term abstinence rates are less optimal. These approved pharmacological therapies include 
nicotine replacement, the antidepressant bupropion and the a $4 \beta 2$ receptor partial agonist varenicline. The efficacy of bupropion and varenicline for smoking cessation has raised questions about how a non-nicotine drug can aid in smoking cessation. Here we review recent progress on "mechanism"based medication strategies for the treatment of nicotine dependence at both preclinical and clinical levels. These strategies include various pharmacological agents that target brain ACh, DA, glutamate, GABA and endocannabinoid transmission, and pharmacokinetic approaches that alter blood nicotine concentrations, metabolism and clearance.

\section{ACh-based medication development}

Nicotine replacement Nicotine replacement therapy (NRT) is an early pharmacotherapy approved in the early 1980s for smoking cessation ${ }^{[56]}$. The rationale for NRT is similar to that for methadone or buprenorphine for the treatment of opiate dependence. That is, NRT uses safe delivery forms of nicotine to replace the nicotine obtained from cigarettes, thereby eliminating tobacco smoking and tobaccorelated illnesses. Various NRTs are currently available and include gums, transdermal patches, lozenges, tablets, and inhalers. NRTs have been shown to be effective in aiding abstinence from cigarette smoking behavior, reducing the rewarding effects produced by nicotine from cigarettes, attenuating affective and somatic withdrawal symptoms, relieving craving and reducing relapse risk. However, efficacy is low and only lasts for a short period of time. At best only about $20 \%$ of smokers are able to maintain long-term abstinence with any of these approaches, and first year relapse rates are as high as $80 \%$. The reasons underlying such low efficacy of NRTs are unclear, but likely to be related to their relatively poor pharmacokinetic properties compared to nicotine delivered via smoking. Thus, much research has been directed to develop other non-nicotine strategies for the facilitation of smoking cessation.

Nonselective $n A C h R$ antagonists In theory, a nonselective $\mathrm{nAChR}$ antagonist would block the physiological and reinforcing effects of cigarette smoking, and thereby lead to extinction of cigarette smoking behavior. A possible sideeffect is that an antagonist may precipitate withdrawal symptoms, and thus increase the risk of relapse to cigarette smoking.

Mecamylamine Mecamylamine is a non-competitive nicotinic antagonist, originally used as an antihypertensive agent ${ }^{[57]}$. Widely used in the 1950 s, this orally effective antihypertensive agent is now rarely used because of its widespread ganglionic side-effects at antihypertensive doses. However, recent studies suggest that mecamylamine, at relatively low doses, significantly attenuates the physiological and rewarding effects of nicotine, and improves abstinence rates in smoking cessation studies, particularly for women ${ }^{[58]}$. In particular, mecamylamine, when combined with NRT, significantly reduces craving for cigarettes and produces prolonged abstinence rates (37.5\% versus $4.2 \%$ for 12 months) when compared with NRT alone ${ }^{[59]}$. Preclinical studies demonstrate that mecamylamine attenuates intravenous self-administration of nicotine ${ }^{[3,60,61]}$, reduces nicotine-enhanced brainstimulation reward ${ }^{[62]}$, blocks nicotine-conditioned place preference $^{[63]}$, and inhibits the stimulant effect of nicotine on locomotor activity ${ }^{[64]}$. In contrast, it has also been reported that mecamylamine causes an increase rather than a decrease in smoking behavior, likely a compensatory response to partially reduced nicotine reward ${ }^{[65]}$. Further, a recent study did not find an added benefit of combining mecamylamine with use of a transdermal nicotine patch ${ }^{[66]}$. Thus, further studies are required to confirm mecamylamine's efficacy for smoking cessation. Mecamylamine is currently in Phase III clinical trials in the United States, and is not yet approved by the US Food and Drug Administration (FDA) for smoking cessation.

$n A C h R$ partial agonists Given the central role of $\alpha_{4} \beta_{2}$ nAChRs in nicotine reward as noted above, modulating the activity of these receptors is expected to have therapeutic benefits. Partial agonists, by definition, have lower intrinsic functional activity, and therefore, produce a smaller maximal effect at full receptor occupancy than do full agonists. By mimicking some of the agonist rewarding effects of nicotine, partial $\alpha_{4} \beta_{2}$ nAChR agonists should, theoretically, relieve craving and withdrawal symptoms during abstinence. In addition, high affinity $\alpha 4 \beta 2 \mathrm{nAChR}$ partial agonists may also prevent nicotine binding to $\alpha 4 \beta 2 \mathrm{nAChRs}$, therefore producing an "antagonistic" anti-nicotine effect. These considerations prompted the search for ligands that act as partial agonists at the $\alpha_{4} \beta_{2}$ nAChR subtype of as novel treatments for smoking cessation.

Varenicline Varenicline is a partial agonist at $\alpha 4 \beta 2$ and a full agonist at $\alpha 7$ nicotinic receptors ${ }^{[67,68]}$. Both chemically and pharmacologically, varenicline is similar to cytisine, a plant alkaloid with high affinity for several subtypes of nAChRs ${ }^{[69]}$. Cytisine has been used in Eastern Europe for over 40 years as a treatment for tobacco dependence in the form of an extract from the herb Cytisus Laborinum L (Golden Rain acacia) ${ }^{[70]}$. In 1994, it was reported that cytisine is a weak partial agonist at nAChRs with limited absorption into the brain ${ }^{[71]}$, providing an additional rationale for the use of partial agonists for smoking cessation. Direct chemical modifications of cytisine have lead to two novel highly potent and selective $\alpha 4 \beta 2 \mathrm{nAChR}$ partial ago- 
nists-varenicline and dianicline. Varenicline, developed by Pfizer Inc, has been approved by the US FDA as a therapeutic aid to quit smoking, while dianicline, developed by SanofiAventis, is currently under Phase III clinical trials ${ }^{[69,72,73]}$.

Preclinical studies demonstrate that varenicline elevates extracellular DA in the shell of the NAc, an effect that is weaker than that evoked by nicotine. Pretreatment with varenicline significantly inhibits nicotine-enhanced NAc DA and nicotine self-administration ${ }^{[69,72,73]}$. Varenicline itself partially substitutes for nicotine in animal self-administration paradigms and partially generalizes to nicotine as a discriminative stimulus ${ }^{[6,74]}$. Consistent with these findings, we have recently reported that varenicline also significantly inhibits nicotine-enhanced electrical brain-stimulation reward, an effect that is mediated by activation of $\alpha 4 \beta 2$, but not $\alpha 7$, $n A C h R s^{[75]}$. It has also been reported that varenicline significantly reduces ethanol, but not sucrose, self-administration, and decreases voluntary ethanol, but not water, consumption in rats ${ }^{[76]}$. Clinical trials indicate superior efficacy of varenicline over placebo and bupropion for achieving abstinence from smoking, and varenicline has also been shown to significantly delay smoking relapse ${ }^{[73,77,78]}$. The safety profile of varenicline is generally good, with the most commonly occurring adverse event being nausea ${ }^{[79]}$. However, new safety warnings were added to the varenicline label in early 2008 because of post-marketing reports of neuropsychiatric symptoms including agitation, depression and suicidality ${ }^{[79]}$. A causal relationship between varenicline use and these symptoms has not been established.

Nicotine metabolism inhibitors In addition to targeting nAChRs, another approach is to elevate blood nicotine concentrations by reducing nicotine metabolism, thereby decreasing the number of cigarettes smoked ${ }^{[80]}$. In humans, approximately $80 \%$ of absorbed nicotine is metabolized to cotinine by the hepatic enzyme CYP2A $6^{[81]}$. Nicotine is also excreted unchanged and metabolized to other minor metabolites, but these pathways account for only a small portion of nicotine. Based on this, it has been proposed that CYP2A6 inhibitors may have therapeutic potential for the treatment of tobacco dependence ${ }^{[82]}$. In support of this hypothesis, it was reported that the strong CYP2A6 inhibitors methoxsalen and tranylcypromine significantly elevate plasma nicotine levels during smoking or NRT treatment ${ }^{[83,84]}$ and significantly decrease the desire to smoke ${ }^{[85]}$. Similarly, human subjects with genetically low CYP2A6 activity have an increased likelihood (1.75 fold) of quitting smoking ${ }^{[86]}$, suggesting that CYP2A6 inhibitors may hold some promise for smoking cessation.

Selegiline Compared to other CYP2A6 inhibitors, sele- giline is not only a competitive CYP2A6 inhibitor, but also a selective and irreversible monoamine oxidase $\mathrm{B}$ (MAO-B) inhibitor. In the brain, MAO-B is the major enzyme that, together with $\mathrm{MAO}-\mathrm{A}$, metabolizes brain $\mathrm{DA}^{[87]}$. Since $\mathrm{MAO}-\mathrm{B}$ activity is $40 \%$ lower in the brain of smokers compared to nonsmokers ${ }^{[88]}$, and this decrease in MAO-B is reversed during long-term smoking abstinence ${ }^{[89]}$, it has been suggested that a tobacco smoke component with MAO-B inhibition activity may contribute to the rewarding effects of cigarette smoking ${ }^{[90,91]}$. Based on this, selegiline has been investigated as a potential therapy for smoking cessation. Several clinical studies suggest that selegiline is effective in reducing withdrawal symptoms and increasing abstinence compared with placebo. For instance, selegiline has been shown to significantly reduce smoking satisfaction during smoking and decrease craving during abstinence ${ }^{[92]}$. In addition, it has also been reported that oral selegiline increases smoking cessation trial endpoint (8-week) abstinence compared with placebo by 3 -fold ${ }^{[93]}$. When combined with nicotine patch, selegiline doubled the 52-week continuous abstinence rate compared with nicotine patch alone ${ }^{[94]}$. In addition, there is no evidence indicating that selegiline is addictive $^{[95]}$. Taken together, selegiline may have therapeutic potential for smoking cessation by inhibiting both nicotine and DA metabolism.

Nicotine vaccines The nicotine vaccine is a newer strategy being investigated for smoking cessation. The principle of this strategy is to prevent nicotine from entering the brain. In immunized individuals, nicotine obtained from smoking is bound by nicotine-specific antibodies and cannot cross the blood-brain barrier, thus preventing its central effects. Since nicotine itself is not immunogenic, it must be conjugated to larger carrier proteins that can act as immunogenic molecules. Currently, there are at least five companies developing nicotine vaccines using different antigenic molecular approaches. An advantage of nicotine vaccines is that daily administration of the drug is not required, and only occasional booster shots are needed to maintain an adequate antibody titer. A major concern with nicotine vaccines is that the titer of antibodies after immunization may not be sufficient to sequester all of the nicotine in blood, limiting vaccine utility for preventing nicotine entry into the brain during smoking ${ }^{[80]}$.

Preclinical studies indicate that passive immunization in rats with nicotine antibodies prevents nicotine-conditioned place preference and attenuates withdrawal symptoms ${ }^{[96]}$. Active immunization with nicotine vaccines significantly reduces $(\sim 65 \%)$ nicotine distribution into the brain ${ }^{[97]}$, and inhibits nicotine self-administration, although it failed to 
prevent the acquisition of nicotine self-administration ${ }^{[98]}$. In addition, active immunization also significantly prevents nicotine-triggered reinstatement of nicotine-seeking behavior ${ }^{[99]}$. Small-size clinical trials indicate that high doses of nicotine vaccine significantly increase continuous abstinence rates compared with placebo ( $38 \%$ vs $10 \%$ for 30 days), and do not cause compensatory smoking behaviors or precipitate withdrawal ${ }^{[100]}$. There are two nicotine vaccines, developed by Cytos Biotechnology (http://www.cytos.com) and Nabi Biopharmaceuticals (NicVAXTM) (http://www. nabi.com), which are currently under Phase II clinical trials for smoking cessation. High abstinence rates were achieved with nicotine vaccines compared with the placebo (57\% versus $31 \%$ at 6 months; $42 \%$ versus $21 \%$ at 12 months). So far, there have been no serious adverse events associated with such vaccines ${ }^{[80,100]}$. These data suggest that nicotine vaccines may be useful for smoking cessation treatment.

DA-based medication development As noted above, the mesolimbic DA system is critically involved in drug reward and addiction, including addiction to nicotine ${ }^{[101,102]}$. Based on this, much work on the development of new medications for treatment of tobacco addiction has focused on manipulation of DA transmission in the reward circuitry of the brain. Two major pharmacological strategies of manipulating brain DA transmission have emerged as the basis for anti-nicotine medication development: one being to target brain DA receptors with either partial agonists or antagonists, and another being to target brain DA transporters. Although both $\mathrm{DA} \mathrm{D}_{1}$ and $\mathrm{D}_{2}$ receptors have been shown to be critically involved in drug reward and addiction ${ }^{[103,104]}$, clinical trials with $\mathrm{D}_{1}$ - or $\mathrm{D}_{2}$-like receptor antagonists have failed, due to lack of therapeutic effect with $D_{1}$-like antagonists or severe side-effects with $\mathrm{D}_{2}$-like antagonists - such as dysphoria, suppression of natural reward or abnormal movements ${ }^{[105]}$. In marked contrast to $D A D_{1}$ and $D_{2}$ receptors, the $D_{3}$ receptor subtype has a restricted distribution in the brain; that is, $\mathrm{D}_{3}$ receptors are selectively expressed in the mesolimbic DA system with the highest receptor densities in the NAc, islands of Calleja and olfactory tubercle ${ }^{[106,107]}$. This restricted neuroanatomic localization suggests that $\mathrm{D}_{3}$ receptors may play an important role in drug reward and addiction ${ }^{[108]}$. In addition, $\mathrm{D}_{3}$ receptors have the highest affinity for endogenous DA of all known receptors ${ }^{[109,110]}$, suggesting a crucial role for $\mathrm{D}_{3}$ receptors in the normal functioning of the mesolimbic DA system. Moreover, chronic exposure to nicotine significantly increases the expression of $\mathrm{D}_{3}$ receptor binding and mRNA levels in the mesolimbic DA system ${ }^{[111]}$. Based on this, it has been hypothesized that selective $\mathrm{D}_{3}$ receptor partial agonists or antagonists would be effective in the treatment of nicotine dependence ${ }^{[108,109,112]}$.

$D \mathrm{~A}_{3}$ receptor partial agonists or antagonists The rationale for $\mathrm{D}_{3}$ partial agonists as novel treatments for tobacco dependence is that: 1) $\mathrm{D}_{3}$ partial agonists are expected to modestly activate $\mathrm{D}_{3}$ receptors, and therefore blunt cigarette craving and withdrawal during abstinence; and 2) D3 partial agonists would have additional therapeutic anti-nicotine benefit by blocking nicotine-enhanced DA binding to $\mathrm{D}_{3}$ receptors. In other words, such a compound can act either as an agonist or antagonist depending on the prevailing DA tone.

BP-897 BP-897 is the first developed $\mathrm{D}_{3}$-selective partial agonist ${ }^{[113]}$. It has modest (60-70 fold) selectivity for human $\mathrm{D}_{3}$ versus $\mathrm{D}_{2}$ receptors, and similar (60-70 fold) selectivity over other receptors including $\alpha_{1^{-}}, \alpha_{2}$-adrenergic, and $5-\mathrm{HT}_{1 \mathrm{~A}}$ receptors ${ }^{[113]}$. In experimental animals, BP-897 produces a significant dose-dependent reduction in the expression of nicotine-induced $\mathrm{CPP}^{[111]}$, nicotine-enhanced brain stimulation reward (Xi and Gardner, unpublished data), nicotine-conditioned locomotor responses, and nicotine-induced increases in $\mathrm{D}_{3}$ receptor expression in the $\mathrm{NAc}^{[111,114]}$. In contrast, BP-897 failed to alter the doseresponse curve for nicotine drug discrimination. When substituted for the training dose of nicotine, BP-897 did not produce nicotine-like discriminative-stimulus effects ${ }^{[111]}$. In addition, BP-897 fails to alter locomotor activity and foodmaintained behavior ${ }^{[115]}$. These findings suggest that BP-897 may selectively reduce the motivational effects of nicotine without significant unwanted side-effects by itself. However, enthusiasm for BP-897 has waned due to recent findings that BP-897 also displays full antagonist properties at both DA $D_{2}$ and $D_{3}$ receptors ${ }^{[116-118]}$, suggesting that its therapeutic anti-nicotine effects could be mediated by blockade of $\mathrm{D}_{2}$ and/or $\mathrm{D}_{3}$ receptors. Since $\mathrm{D}_{2}$ receptor antagonism usually produces severe unwanted side-effects, such as dysphoria, inhibition of natural reward, and abnormal extra-pyramidal movements ${ }^{[103-105]}$, it is suggested that BP-897, at high doses, may also produce such side-effects at the human level. BP-897 has recently entered Phase II clinical studies, but detailed pharmacokinetic and toxicological data have not yet been reported.

SB-277011A SB-277011A is the most well characterized full $\mathrm{D}_{3}$ receptor antagonist to date. SB-277011A has high affinity for the human cloned $\mathrm{DA} \mathrm{D}_{3}$ receptor, and the ratio of in vitro $\mathrm{D}_{3} / \mathrm{D}_{2}$ affinity of SB-277011A for human and rat is 120 and 80 , respectively ${ }^{[119]}$. SB-277011A has a 100 fold or better selectivity over 180 other receptors, enzymes and ion channels ${ }^{[119]}$. A series of studies has assessed the efficacy of SB-277011A in animal models of nicotine dependence ${ }^{[120,121]}$. SB-277011A significantly inhibits 
nicotine self-administration under progressive-ratio (PR), but not low FR reinforcement schedules ${ }^{[122,123]}$, nicotineinduced $\mathrm{CPP}^{[7]}$, nicotine-enhanced brain reward, and nicotine-paired environmental cue functions ${ }^{[7]}$. In addition, SB-277011A also inhibits nicotine-induced reinstatement of drug-seeking behaviors ${ }^{[122]}$ and nicotine cue-induced conditioned locomotor activity ${ }^{[7,114]}$. However, further development of SB-277011A has been halted by Glaxo-SmithKline Pharmaceuticals, due to unexpectedly poor bioavailability $(\sim 2 \%)$ and a very short half-life $(<20 \mathrm{~min})$ in primates ${ }^{[124]}$. Therefore, development of other $\mathrm{D}_{3}$-selective antagonists with higher bioavailability and more promising pharmacotherapeutic profiles is required ${ }^{[125]}$. There are two novel DA D3 receptor-selective antagonists, GSK598809, and GSK618334, which are currently under clinical phase I for the treatment of drug addiction, including nicotine dependence (http://clinicaltrials.gov/ct2/results?term=GSK-618334).

$D A$ transporter (DAT) inhibitors Although there is no evidence that nicotine can act directly on the DAT protein, several studies suggest a potential relationship ${ }^{[126]}$. First, a single dose of nicotine enhances DA clearance in rat NAc, suggesting that nicotine regulates extracellular DA concentration via the $\mathrm{DAT}^{[127]}$; and second, $\mathrm{nAChR}$ activation by acute and chronic nicotine augments amphetamineinduced reverse transport of DA by the $\mathrm{DAT}^{[128,129]}$. This DA enhancement by nicotine was fully reversed by the nicotinic receptor antagonists $\mathrm{DH} \beta \mathrm{E}$ and mecamylamine, suggesting that $\mathrm{nAChRs}$ modulate DAT function ${ }^{[128]}$.

Bupropion Bupropion is an efficacious antidepressant and smoking cessation agent which inhibits the DAT and the norepinephrine transporter in addition to acting as a nicotinic antagonist at $\alpha 3 \beta 2$ and $\alpha 3 \beta 4 \mathrm{nAChRs}$ in rat striatum and hippocampus ${ }^{[130]}$. Bupropion is endorsed by the US Clinical Practice Guideline as a first-line pharmacotherapy for treatment of tobacco abstinence ${ }^{[56]}$. Since tobacco smokers undergoing cessation often experience symptoms of depression $^{[130,131]}$, it is speculated that bupropion's pharmacotherapeutic efficacy may be mediated by its antidepressant effects combined with blockade of the DAT and some nAChRs. In animal studies, acute administration of bupropion attenuated both nicotine-enhanced brain-stimulation reward and the brain-stimulation inhibition associated with nicotine withdrawal ${ }^{[132]}$. Also, bupropion blocks the acquisition of nicotine-induced CPP and mecamylamine-precipitated withdrawal ${ }^{[133]}$. In the self-administration paradigm, bupropion produces a biphasic effect: low dose bupropion increases, whereas high dose bupropion decreases, nicotine self-administration in rats ${ }^{[134]}$. The increase in nicotine self-administration could be a compensatory response to a reduction in nicotine reward after low doses of bupropion. In humans, the majority of studies have demonstrated that bupropion is more effective at improving smoking cessation than placebo ${ }^{[135,136]}$. Bupropion has also been reported to reduce nicotine abstinence-associated depression, difficulty concentrating, and irritability, relative to placebo ${ }^{[137]}$. A recent meta-analysis of several trials shows that bupropion nearly doubles smoking cessation rates with a similar efficacy to NRT $^{[138,139]}$.

Glutamate-based medication development Glutamate is the major excitatory neurotransmitter in the brain and plays a critical role in the acute and long-term effects of nicotine. The actions of glutamate are mediated by both ionotropic (iGluR) and metabotropic (mGluR) glutamate receptors. The iGluRs include N-methyl-D-aspartate (NMDA), a-amino-3-hydroxy-5-methyl-4-isoxazolepropionate (AMPA) and kainate receptors, which are located primarily on postsynaptic cells and regulate cellular excitability by opening glutamate-gated ion channels. The mGluRs are classified into three groups based on sequence homology, signal transduction pathways and pharmacological actions. Group I (mGluR1 and mGluR5) receptors are predominately located postsynaptically where they couple to $\mathrm{G}_{\mathrm{q}}$-proteins to activate phospholipase C. Group II (mGluR2 and mGluR3) and Group III (mGluR4, mGluR6, mGluR7 and mGluR8) receptors are primarily found presynaptically and on glial cells, and couple to $G_{i / o}$ proteins to negatively regulate adenylyl cyclase activity. Activation of group II or III mGluRs negatively modulates glutamate release.

Nicotine binds with high affinity to nAChRs located on presynaptic glutamatergic terminals in various brain sites, including the VTA, NAc, prefrontal cortex and hippocampus, producing an increase in glutamate release ${ }^{[32,140,141]}$. In the VTA, the $\alpha 7 \mathrm{nAChR}$ subtype has been shown to be localized on VTA DA neurons ${ }^{[31,32]}$ and presynaptic glutamatergic afferents ${ }^{[142]}$. Activation of the $\alpha 7$ receptors by nicotine increases glutamate release in the VTA and activates iGluRs located postsynaptically on VTA DA neurons (Figure 1), with the end result being an increase in the activity of the mesolimbic reward circuit ${ }^{[139,141]}$. Behaviorally, repeated administration of nicotine causes a long-lasting motor sensitization $^{[143,144]}$ that has been suggested to play a role in nicotine's addictive properties ${ }^{[145]}$. Glutamatergic and dopaminergic mechanisms within the VTA and NAc have been implicated in this nicotine sensitization ${ }^{[145]}$. Pharmacological studies on nicotine reinforcement, relapse, and withdrawal have provided important information regarding possible glutamate-based interventions for the treatment of nicotine addiction ${ }^{[141]}$. The effects of glutamate compounds on nico- 
tine dependence are likely to be mediated by attenuation of nicotine-stimulated glutamate transmission in the mesolimbic system via blockade of either presynaptic mGluR2/3 receptors or postsynaptic mGluR5 or NMDA receptors.

$m G l u R 2 / 3$ receptor agonists Considering that $\mathrm{mGluR} 2 / 3$ are located presynaptically and negatively modulate glutamate release, it has been proposed that activation of mGluR $2 / 3$ receptors by agonists would decrease presynaptic glutamate release, and therefore block the rewarding effects of nicotine and cigarette smoking.

LY379268 LY379268 is a potent, systemically active mGluR2/3 agonist. Systemic or local administration of LY379268 into the posterior VTA or the NAc shell dose dependently inhibits nicotine self-administration at doses that have no effect on food-taking behavior. LY379268 also reverses cue-induced reinstatement of both nicotine- and food-seeking behaviors ${ }^{[146]}$. In addition, LY379268 attenuates reward deficits associated with spontaneous nicotine withdrawal in rats ${ }^{[147]}$. However, when LY379268 is given alone, it inhibits brain-stimulation reward in rats ${ }^{[148]}$. These data suggest that LY379268 or other mGluR2/3 agonists may have some utility for the treatment of nicotine withdrawal and dependence. However, LY379268, at doses that inhibited cue-induced reinstatement of nicotine seeking, also inhibited food seeking, suggesting that stimulatory actions at presynaptic inhibitory mGluR2/3 have general effects on the motivational impact of conditioned reinforcers. In addition, rapid tolerance occurred to the LY379268-induced decreases in nicotine self-administration ${ }^{[146]}$, which may also limit the potential use of this compound for the treatment of nicotine dependence.

$m$ GluR5 receptor antagonists The mGluR5 receptor has become an important target in medication discovery for treatment of addiction, largely because of its relatively selective regional distribution in the brain and predominantly postsynaptic location ${ }^{[149]}$. mGluR5 blockade has been proposed to attenuate nicotine-enhanced glutamate transmission in the mesolimbic DA system, and therefore attenuating the rewarding effects of nicotine. A large body of literature indicates that mGluR5s play an important role in behavioral responses to nicotine.

MPEP 2-methyl-6-(phenylethynyl)-pyridine (MPEP) is a selective mGluR5 antagonist. It has been shown to decrease nicotine self-administration in mice and rats ${ }^{[150-152]}$. MPEP also decreases progressive-ratio reinforcement breaking points for nicotine self-administration more than break points for food-taking behavior ${ }^{[153]}$. MPEP also reduces reinstatement of nicotine-seeking behavior induced by a nicotine priming injection ${ }^{[152]}$ or by re-exposure to environmental cues previously associated with nicotine self-administration, but not by cues associated with food-taking behavior ${ }^{[154]}$. However, MPEP does not block the ability of nicotine to enhance brain-reward ${ }^{[140]}$, nor does it block the development of nicotine-induced $\mathrm{CPP}^{[155]}$. Thus, although MPEP may be of some clinical benefit in reducing cigarette smoking or relapse during attempts to quit, it may not significantly attenuate the effects of nicotine on brain reward functions ${ }^{[141]}$. In addition to MPEP, it was recently reported that MTEP (3-[(2-methyl-1,3-thiazol-4-yl)ethynyl]-pyridine), a novel highly selective mGluR5 antagonist, also significantly inhibits nicotine seeking, but does not affect the reinforcement enhancing effects of nicotine ${ }^{[156]}$.

NMDA receptor antagonists NMDA receptor blockade either globally via systemic administration of an NMDA receptor antagonist or locally via injections of an NMDA receptor antagonist directly into the VTA or the central nucleus of the amygdala-decreases intravenous nicotine selfadministration in rats ${ }^{[157]}$. The effects of NMDA receptor antagonists on intravenous nicotine self-administration occur at doses that do not effect responding for food reinforcement under similar schedules of reinforcement.

Memantine Memantine is a non-competitive, selective NMDA receptor antagonist ${ }^{[158]}$, and is clinically used for the treatment of dementia. The efficacy of memantine for the treatment of nicotine addiction has been investigated as well. In a preclinical study, memantine was found to block the acquisition of nicotine self-administration ${ }^{[159]}$. However, in humans, memantine does not influence cigarette consumption, craving, or estimation of nicotine's hedonic effects under conditions of instructed smoking reduction, nor does it significantly disturb sensory components of learning mechanisms relevant for the acquisition and maintenance of nicotine dependence ${ }^{[160]}$.

GABA-based medication development GABA is the most important inhibitory neurotransmitter in the mammalian CNS and it has been shown to play an important role in mediating the reinforcing effects of nicotine. GABAergic afferents to the VTA originate from the pedunculopontine tegmental nucleus, ventral pallidum and NAc. Also, GABAergic interneurons within the VTA exert inhibitory control over VTA DA neurons ${ }^{[161]}$. The central effects of GABA are mediated by both ionotropic $\mathrm{GABA}_{\mathrm{A}}$ and metabotropic $G_{A B A_{B}}$ receptors. $G_{A B A_{A}}$ receptors are located predominantly on postsynaptic cells and functionally lower their excitability. In contrast, $\mathrm{GABA}_{B}$ receptors are predominantly located on presynaptic terminals, and inhibit presynaptic neurotransmitter release. Consequently, any pharmacological strategy that increases GABAergic trans- 
mission within brain reward circuits by either elevating extracellular GABA levels or directly activating GABA receptors would inhibit nicotine-induced increases in NAc DA and subsequent nicotine reinforcement ${ }^{[132]}$.

Gamma-vinyl GABA ( $G V G$, vigabatrin) $\mathrm{GVG}$ is an irreversible inhibitor of GABA transaminase, the primary enzyme involved in GABA metabolism ${ }^{[162]}$. GABA transaminase is essential for GABA's metabolic breakdown, and therefore its inhibition elevates brain GABA levels. GVG has been shown to dose-dependently attenuate nicotine-induced increases in extracellular DA in the NAc ${ }^{[163]}$. GVG also decreases nicotine self-administration ${ }^{[164]}$ and abolishes both the acquisition and the expression of nicotine-conditioned place preference ${ }^{[165]}$. In addition, GVG dose-dependently lowers nicotine-induced increases in NAc DA in both naive and chronically nicotine-treated rats, and blocks nicotineinduced increases in striatal DA in non-human primates as measured by positron emission tomography ${ }^{[166]}$. These results suggest that GVG may have potential utility as an antinicotine therapeutic medication. GVG is currently in Phase II clinical trials for cocaine dependence, but not for nicotine dependence.

Baclofen Baclofen is a systemically active $\mathrm{GABA}_{\mathrm{B}}$ receptor agonist. It has been reported that baclofen dose-dependently inhibits nicotine-induced increases in NAc DA release ${ }^{[167]}$. Systemic injections or microinjections of baclofen into the VTA, NAc shell, or pedunculopontine tegmental nucleus (that sends cholinergic, GABAergic and glutamatergic projections to the VTA) inhibits nicotine self-administration in rats and mice ${ }^{[35,168-171]}$. In addition, baclofen, at high doses, completely inhibits nicotine-induced CPP and foodreinforced responding, but fails to reduce nicotine's drug discriminative effects ${ }^{[49]}$. A small-scale clinical study (16 patients) indicated that a single dose of baclofen $(20 \mathrm{mg} /$ $\mathrm{kg}$ ) significantly altered the sensory properties of smoked cigarettes (eg, increasing ratings of 'harsh' and decreasing ratings of 'like cigarette's effects), produced mild sedativelike effects, but failed to reduce cigarette craving or the number of cigarettes smoked ${ }^{[172]}$. Large-scale clinical trials with multiple drug treatment regimens are required for fully evaluating baclofen's efficacy in the treatment of nicotine dependence. On a cautionary note, baclofen may have undesired side-effects, as indicated by preclinical findings that high dose baclofen significantly inhibited locomotor activity and rotarod locomotor performance ${ }^{[49,173]}$, and decreased responding for non-drug rewards, such as food and electrical brain stimulation reward ${ }^{[164,171,174]}$.

GS39783 and BHF177 GS39783 and BHF177 are novel $\mathrm{GABA}_{B}$ receptor-positive allosteric modulators ${ }^{[175,176]}$. Since positive allosteric modulators bind to a site distinct from the agonist binding pocket, they do not alter or perturb receptor signaling on their own, but potentiate the effect of GABA when endogenous GABA is released. Recent studies demonstrate that such positive allosteric compounds significantly inhibits nicotine self-administration under both FR and PR reinforcement schedules and attenuates nicotine-induced CPP and nicotine-enhanced brain-stimulation reward ${ }^{[177,178]}$. Strikingly, these effects were seen at a range of doses that neither altered food-taking behavior nor impaired rotarod locomotor performance in rats ${ }^{[173,178]}$. These findings suggest that $\mathrm{GABA}_{\mathrm{B}}$ receptor positive allosteric modulators may have similar pharmacotherapeutic effects for smoking cessation as the full $\mathrm{GABA}_{\mathrm{B}}$ receptor agonist baclofen, but with fewer side-effects.

\section{Endocannabinoid-based medication develop-} ment Recent studies suggest that the endocannabinoid system also plays an important role in nicotine's addictive properties $^{[179,180]}$. This is supported by evidence that: 1) coadministration of sub-threshold doses of a cannabinoid agonist and nicotine produces an enhanced rewarding effect ${ }^{[181]}$; 2) chronic administration of nicotine in rats produces increases in endocannabinoid (anandamide) levels in the limbic forebrain and in both anandamide and 2-arachidonolyglycerol in the brainstem, although $\mathrm{CB}_{1}$ receptor binding and CB1 mRNA levels were not affected ${ }^{[182]}$; 3 ) the rewarding effects of nicotine, assessed in the CPP paradigm, are absent in CB1 receptor knockout mice ${ }^{[183]}$, though the absence of $\mathrm{CB} 1$ receptors does not modify the acquisition of nicotine self-administration ${ }^{[184]}$; and 4) endocannabinoid agonists have been shown to facilitate DA neuron activity in the VTA and increase DA release in the NAc ${ }^{[185]}$, whereas cannabinoid $\mathrm{CB} 1$ receptor antagonists inhibit nicotine self-administration and nicotine-seeking behavior ${ }^{[181,186]}$. It is generally believed that such cannabinoid effects are mediated by activation of CB1 receptors located on presynaptic GABAergic neurons in the VTA and/or the NAc, causing a decrease in GABA release and an increase in NAc DA release ${ }^{[181]}$. Based on this, CB1 receptor antagonists may have utility for smoking cessation.

SR141716A (Rimonabant) SR141716A is the first developed CB1 receptor antagonist ${ }^{[187]}$, and has become an important tool for research on cannabinoid involvement in nicotine's addictive properties. In preclinical studies, rimonabant dose-dependently blocks the nicotine-induced elevations in NAc DA and attenuates nicotine self-administration ${ }^{[188]}$. Rimonabant also attenuates the expression and development of nicotine-induced $\mathrm{CPP}^{[189,190]}$ and blocks environmental cue-induced reinstatement of nicotine-seeking ${ }^{[180,181]}$. In 
humans, one trial gave both rimonabant and a nicotine patch or rimonabant and a placebo patch to smokers who were motivated to quit. The rimonabant and nicotine patch produced abstinence rates of $39 \%$ during weeks $6-9$ of treatment, compared with $21.3 \%$ of patients treated with rimonabant and placebo ${ }^{[191]}$. However, it has been recently reported that rimonabant increases anxiety and depressive symptoms ${ }^{[192,193]}$. Because of these potential adverse effects, the US FDA has not currently approved its use in humans.

AM251 AM251 is a novel CB1 antagonist, structurally similar to rimonabant ${ }^{[194,195]}$. AM251 reverses locomotor sensitization to a nicotine challenge and nicotine-induced elevations in extracellular serotonin in the rat hippocampus $^{[196]}$. AM251 also dose-dependently suppresses intravenous nicotine self-administration in rats. The self-administration behavior was reinstated by suspending AM251 treatment. Also, pretreatment with AM251 dose-dependently attenuates nicotine-induced and nicotine-associated cueinduced relapse to nicotine-seeking behavior ${ }^{[197]}$. AM251 has not yet been evaluated clinically.

\section{Conclusion}

Given the prevalence and serious consequences of smoking and nicotine dependence, the development of effective therapies to aid smoking cessation is imperative. In this article, we have reviewed the neurochemical bases underlying the pharmacological actions of nicotine and nicotine reinforcement, and evaluated the pharmacological actions of a number of promising agents that target brain substrates on which nicotine acts in both preclinical and clinical models. Though these compounds are different pharmacologically and mechanistically, they all work by interfering with nicotine's actions in the mesolimbic DA reward and relapse system. Recent success with some of these compounds, such as varenicline and bupropion, highlights the importance of preclinical medication development with animal models of drug dependence. These mechanism-based pharmacological strategies may lead to more novel compounds for evaluation in human trials for smoking cessation. If any one demonstrates significant anti-nicotine reward, anti-nicotine craving and anti-relapse efficacy in humans, the beneficial impact on addiction medicine will be considerable.

\section{Acknowledgements}

This research was supported by the Intramural Research Program of the National Institute on Drug Abuse, National Institutes of Health.

\section{References}

1 Centers for Disease Control and Prevention C. Cigarette smoking among adults- United States, 2006. In Morbidity and Mortality Weekly Report. 2007; serial online.

2 Who Report on the Global Tobacco Epidemic. The MPOWER Package. Geneva, World Health Organization, 2008. www.who. int/tobacco/mpoewer/mpower_report.

3 Goldberg SR, Spealman RD, Goldberg DM. Persistent behavior at high rates maintained by intravenous self-administration of nicotine. Science 1981; 214: 573-5.

4 Watkins SS, Koob GF, Markou A. Neural mechanisms underlying nicotine addiction: acute positive reinforcement and withdrawal. Nicotine Tob Res 2000; 2: 19-37.

5 Clarke PB, Kumar R. The effects of nicotine on locomotor activity in non-tolerant and tolerant rats. Br J Pharmacol 1983; 78: 329-37.

6 Clarke PB. Dopaminergic mechanisms in the locomotor stimulant effects of nicotine. Biochem Pharmacol 1990; 40: 1427-32.

7 Pak AC, Ashby CR Jr, Heidbreder CA, Pilla M, Gilbert J, Xi ZX, et al. The selective dopamine D3 receptor antagonist SB-277011A reduces nicotine-enhanced brain reward and nicotine-paired environmental cue functions. Int J Neuropsychopharmacol 2006; 9: 585-602.

8 Corrigall WA. Nicotine self-administration in animals as a dependence model. Nicotine Tob Res 1999; 1: 11-20.

9 Di Chiara G. Role of dopamine in the behavioural actions of nicotine related to addiction. Eur J Pharmacol 2000; 393: 295314.

10 Rosecrans JA, Villanueva HF. Discriminative stimulus properties of nicotine: mechanisms of transduction. NIDA Res Monogr 1991; (116): 101-16.

11 Epping-Jordan MP, Watkins SS, Koob GF, Markou A. Dramatic decreases in brain reward function during nicotine withdrawal. Nature 1998; 393: 76-9.

12 Dani JA, De Biasi M. Cellular mechanisms of nicotine addiction. Pharmacol Biochem Behav 2001; 70: 439-46.

13 Jones S, Sudweeks S, Yakel JL. Nicotinic receptors in the brain: correlating physiology with function. Trends Neurosci 1999; 22: 555-61.

14 Le Novere N CP, Changeux,JP. The diversity of subunit composition in nAChRs: evolutionary origins, physiologic and pharmacologic consequences. J Neurobiol 2002; 53: 447-56.

15 McGehee DS, Role LW. Physiological diversity of nicotinic acetylcholine receptors expressed by vertebrate neurons. Annu Rev Physiol 1995; 57: 521-46.

16 Wonnacott S. Presynaptic nicotinic ACh receptors. Trends Neurosci 1997; 20: 92-8.

17 Buchhalter AR, Fant RV, Henningfield JE. Novel pharmacological approaches for treating tobacco dependence and withdrawal: current status. Drugs 2008; 68: 1067-88.

18 Wise RA. Dopamine, learning and motivation. Nat Rev Neurosci 2004; 5: 483-94.

19 Dani JA, Heinemann S. Molecular and cellular aspects of nicotine abuse. Neuron 1996; 16: 905-8.

20 Corrigall WA, Coen KM, Adamson KL. Self-administered nicotine activates the mesolimbic dopamine system through the ventral tegmental area. Brain Res 1994; 653: 278-84. 
21 Corrigall WA, Franklin KB, Coen KM, Clarke PB. The mesolimbic dopaminergic system is implicated in the reinforcing effects of nicotine. Psychopharmacology (Berl) 1992; 107: 285-9.

22 Watkins SS, Epping-Jordan MP, Koob GF, Markou A. Blockade of nicotine self-administration with nicotinic antagonists in rats. Pharmacol Biochem Behav 1999; 62: 743-51.

23 Cohen C, Bergis OE, Galli F, Lochead AW, Jegham S, Biton B, et al. SSR591813, a novel selective and partial alpha4beta2 nicotinic receptor agonist with potential as an aid to smoking cessation. J Pharmacol Exp Ther 2003; 306: 407-20.

24 Picciotto MR, Zoli M, Rimondini R, Lena C, Marubio LM, Pich $\mathrm{EM}$, et al. Acetylcholine receptors containing the beta2 subunit are involved in the reinforcing properties of nicotine. Nature 1998; 391: 173-7.

25 Marubio LM, Gardier AM, Durier S, David D, Klink R, ArroyoJimenez MM, et al. Effects of nicotine in the dopaminergic system of mice lacking the alpha4 subunit of neuronal nicotinic acetylcholine receptors. Eur J Neurosci 2003; 17: 1329-37.

26 Pidoplichko VI, DeBiasi M, Williams JT, Dani JA. Nicotine activates and desensitizes midbrain dopamine neurons. Nature 1997; 390: 401-4.

27 Klink R, de Kerchove d'Exaerde A, Zoli M, Changeux JP. Molecular and physiological diversity of nicotinic acetylcholine receptors in the midbrain dopaminergic nuclei. J Neurosci 2001; 21: $1452-63$.

28 Wooltorton JR, Pidoplichko VI, Broide RS, Dani JA. Differential desensitization and distribution of nicotinic acetylcholine receptor subtypes in midbrain dopamine areas. J Neurosci 2003; 23: 3176-85.

29 Picciotto MR, Zoli M, Lena C, Bessis A, Lallemand Y, Le Novere $\mathrm{N}$, et al. Abnormal avoidance learning in mice lacking functional high-affinity nicotine receptor in the brain. Nature 1995; 374 : 65-7.

30 Mansvelder HD, McGehee DS. Cellular and synaptic mechanisms of nicotine addiction. J Neurobiol 2002; 53:606-17.

31 Wu J, George AA, Schroeder KM, Xu L, Marxer-Miller S, Lucero $\mathrm{L}$, et al. Electrophysiological, pharmacological, and molecular evidence for alpha7-nicotinic acetylcholine receptors in rat midbrain dopamine neurons. J Pharmacol Exp Ther 2004; 311 : 80-91.

32 Yang K, Hu J, Lucero L, Liu Q, Zheng C, Zhen X, et al. Distinctive nicotinic acetylcholine receptor functional phenotypes of rat ventral tegmental area dopaminergic neurons. J Physiol 2009; 587 (Pt 2): 345-61.

33 Azam L, Winzer-Serhan UH, Chen Y, Leslie FM. Expression of neuronal nicotinic acetylcholine receptor subunit mRNAs within midbrain dopamine neurons. J Comp Neurol 2002; 444: 260-74.

34 Mansvelder HD, McGehee DS. Long-term potentiation of excitatory inputs to brain reward areas by nicotine. Neuron 2000; 27: 349-57.

35 Corrigall WA, Coen KM, Adamson KL, Chow BL, Zhang J. Response of nicotine self-administration in the rat to manipulations of mu-opioid and gamma-aminobutyric acid receptors in the ventral tegmental area. Psychopharmacology (Berl) 2000; 149: 107-14.

36 Markou A. Review. Neurobiology of nicotine dependence. Philos Trans R Soc Lond B Biol Sci 2008; 363: 3159-68.
37 Markou A, Paterson NE. The nicotinic antagonist methyllycaconitine has differential effects on nicotine self-administration and nicotine withdrawal in the rat. Nicotine Tob Res 2001; 3: 361-73.

38 Besson M, Granon S, Mameli-Engvall M, Cloez-Tayarani I, Maubourguet N, Cormier A, et al. Long-term effects of chronic nicotine exposure on brain nicotinic receptors. Proc Natl Acad Sci U S A 2007; 104: 8155-60.

39 Russell MA. Subjective and behavioural effects of nicotine in humans: some sources of individual variation. Prog Brain Res 1989; 79: 289-302.

40 Peng X, Gerzanich V, Anand R, Whiting PJ, Lindstrom J. Nicotine-induced increase in neuronal nicotinic receptors results from a decrease in the rate of receptor turnover. Mol Pharmacol 1994; 46: 523-30.

41 Fenster CP, Hicks JH, Beckman ML, Covernton PJ, Quick MW, Lester RA. Desensitization of nicotinic receptors in the central nervous system. Ann N Y Acad Sci 1999; 868: 620-3.

42 Buisson B, Bertrand D. Chronic exposure to nicotine upregulates the human (alpha)4((beta)2 nicotinic acetylcholine receptor function. J Neurosci 2001; 21: 1819-29.

43 Grottick AJ, Wyler R, Higgins GA. The alpha4beta2 agonist SIB $1765 \mathrm{~F}$, but not the alpha7 agonist AR-R 17779, cross-sensitises to the psychostimulant effects of nicotine. Psychopharmacology (Berl) 2000; 150: 233-6.

44 Shoaib M, Stolerman IP. Locomotor activity after nicotine infusions into the fourth ventricle of rats. Pharmacol Biochem Behav 1994; 48:749-54.

45 Shoaib M, Schindler CW, Goldberg SR. Nicotine self-administration in rats: strain and nicotine pre-exposure effects on acquisition. Psychopharmacology (Berl) 1997; 129: 35-43.

46 O’Brien CP, Gardner EL. Critical assessment of how to study addiction and its treatment: human and non-human animal models. Pharmacol Ther 2005; 108: 18-58.

47 Richardson NR, Roberts DC. Progressive ratio schedules in drug self-administration studies in rats: a method to evaluate reinforcing efficacy. J Neurosci Methods 1996; 66: 1-11.

48 Shalev U, Grimm JW, Shaham Y. Neurobiology of relapse to heroin and cocaine seeking: a review. Pharmacol Rev 2002; 54: $1-42$.

49 Le Foll B, Wertheim CE, Goldberg SR. Effects of baclofen on conditioned rewarding and discriminative stimulus effects of nicotine in rats. Neurosci Lett 2008; 443: 236-40.

50 Wise RA. Neurobiology of addiction. Curr Opin Neurobiol 1996; 6: 243-51.

51 Malin DH, Lake JR, Carter VA, Cunningham JS, Hebert KM, Conrad DL, et al. The nicotinic antagonist mecamylamine precipitates nicotine abstinence syndrome in the rat. Psychopharmacology (Berl) 1994; 115: 180-4.

52 Grabus SD, Martin BR, Batman AM, Tyndale RF, Sellers E, Damaj MI. Nicotine physical dependence and tolerance in the mouse following chronic oral administration. Psychopharmacology (Berl) 2005; 178: 183-92.

53 Malin DH. Nicotine dependence: studies with a laboratory model. Pharmacol Biochem Behav 2001; 70: 551-9.

54 Hildebrand BE, Nomikos GG, Hertel P, Schilstrom B, Svensson $\mathrm{TH}$. Reduced dopamine output in the nucleus accumbens but not in the medial prefrontal cortex in rats displaying a mecamylamine- 
precipitated nicotine withdrawal syndrome. Brain Res 1998; 779: 214-25.

55 Kenny PJ, Markou A. Neurobiology of the nicotine withdrawal syndrome. Pharmacol Biochem Behav 2001; 70: 531-49.

56 Fiore MC. Treating tobacco use and dependence: an introduction to the US Public Health Service Clinical Practice Guideline. Respir Care 2000; 45: 1196-9.

57 Shytle RD, Penny E, Silver AA, Goldman J, Sanberg PR. Mecamylamine (Inversine): an old antihypertensive with new research directions. J Hum Hypertens 2002; 16: 453-7.

58 Rose JE, Behm FM, Westman EC. Nicotine-mecamylamine treatment for smoking cessation: the role of pre-cessation therapy. Exp Clin Psychopharmacol 1998; 6: 331-43.

59 Rose JE, Behm FM, Westman EC, Levin ED, Stein RM, Ripka GV. Mecamylamine combined with nicotine skin patch facilitates smoking cessation beyond nicotine patch treatment alone. Clin Pharmacol Ther 1994; 56: 86-99.

60 Corrigall WA, Coen KM. Nicotine maintains robust selfadministration in rats on a limited-access schedule. Psychopharmacology (Berl) 1989; 99: 473-8.

61 Risner ME, Goldberg SR. A comparison of nicotine and cocaine self-administration in the dog: fixed-ratio and progressive-ratio schedules of intravenous drug infusion. J Pharmacol Exp Ther 1983; 224: 319-26.

62 Ivanova S, Greenshaw AJ. Nicotine-induced decreases in VTA electrical self-stimulation thresholds: blockade by haloperidol and mecamylamine but not scopolamine or ondansetron. Psychopharmacology (Berl) 1997; 134: 187-92.

63 Fudala PJ, Teoh KW, Iwamoto ET. Pharmacologic characterization of nicotine-induced conditioned place preference. Pharmacol Biochem Behav 1985; 22: 237-41.

64 Benwell ME, Balfour DJ, Birrell CE. Desensitization of the nicotine-induced mesolimbic dopamine responses during constant infusion with nicotine. Br J Pharmacol 1995; 114: 45460.

65 Nemeth-Coslett R, Henningfield JE, O’Keeffe MK, Griffiths RR. Effects of mecamylamine on human cigarette smoking and subjective ratings. Psychopharmacology (Berl) 1986; 88: 420-5.

66 Glover ED, Laflin MT, Schuh KJ, Schuh LM, Nides M, Christen AG, et al. A randomized, controlled trial to assess the efficacy and safety of a transdermal delivery system of nicotine/mecamylamine in cigarette smokers. Addiction 2007; 102: 795-802.

67 Foulds J. The neurobiological basis for partial agonist treatment of nicotine dependence: varenicline. Int J Clin Pract 2006; 60: 571-6.

68 Mihalak KB, Carroll FI, Luetje CW. Varenicline is a partial agonist at alpha4beta2 and a full agonist at alpha7 neuronal nicotinic receptors. Mol Pharmacol 2006; 70: 801-5.

69 Rollema H, Coe JW, Chambers LK, Hurst RS, Stahl SM, Williams KE. Rationale, pharmacology and clinical efficacy of partial agonists of alpha4beta2 $\mathrm{nACh}$ receptors for smoking cessation. Trends Pharmacol Sci 2007; 28: 316-25.

70 Scharfenberg G, Benndorf S, Kempe G. [Cytisine (Tabex) as a pharmaceutical aid in stopping smoking]. Dtsch Gesundheitsw 1971; 26: 463-5.

71 Papke RL, Heinemann SF. Partial agonist properties of cytisine on neuronal nicotinic receptors containing the beta 2 subunit. Mol Pharmacol 1994; 45: 142-9.
72 Coe JW, Brooks PR, Vetelino MG, Wirtz MC, Arnold EP, Huang J, et al. Varenicline: an alpha4beta2 nicotinic receptor partial agonist for smoking cessation. J Med Chem 2005; 48: 3474-7.

73 Rollema H, Chambers LK, Coe JW, Glowa J, Hurst RS, Lebel LA, et al. Pharmacological profile of the alpha4beta2 nicotinic acetylcholine receptor partial agonist varenicline, an effective smoking cessation aid. Neuropharmacology 2007; 52: 985-94.

74 Smith JW, Mogg A, Tafi E, Peacey E, Pullar IA, Szekeres P, et al. Ligands selective for alpha4beta2 but not alpha3beta4 or alpha7 nicotinic receptors generalise to the nicotine discriminative stimulus in the rat. Psychopharmacology (Berl) 2007; 190: 15770.

75 Spiller K, Xi XZ, Li X, Ashby CR Jr, Callahan PM, Tehim A, et al. Varenicline attenuates nicotine-enhanced brain stimulation reward by activation of $\alpha 4 \beta 2$ nicotinic receptors in rats. Neuropharmacology 2009; Apr 22 [Epub ahend of print].

76 Steensland P, Simms JA, Holgate J, Richards JK, Bartlett SE. Varenicline, an alpha4beta 2 nicotinic acetylcholine receptor partial agonist, selectively decreases ethanol consumption and seeking. Proc Natl Acad Sci USA 2007; 104: 12518-23.

77 Zierler-Brown SL, Kyle JA. Oral varenicline for smoking cessation. Ann Pharmacother 2007; 41: 95-9.

78 Tutka P. Nicotinic receptor partial agonists as novel compounds for the treatment of smoking cessation. Expert Opin Investig Drugs 2008; 17: 1473-85.

79 Hays JT, Ebbert JO, Sood A. Efficacy and safety of varenicline for smoking cessation. Am J Med 2008; 121: S32-42.

80 Siu EC, Tyndale RF. Non-nicotinic therapies for smoking cessation. Annu Rev Pharmacol Toxicol 2007; 47: 541-64.

81 Messina ES, Tyndale RF, Sellers EM. A major role for CYP2A6 in nicotine C-oxidation by human liver microsomes. J Pharmacol Exp Ther 1997; 282: 1608-14.

82 Siu EC, Wildenauer DB, Tyndale RF. Nicotine self-administration in mice is associated with rates of nicotine inactivation by CYP2A5. Psychopharmacology (Berl) 2006; 184: 401-8.

83 Lerman C, Tyndale R, Patterson F, Wileyto EP, Shields PG, Pinto A, et al. Nicotine metabolite ratio predicts efficacy of transdermal nicotine for smoking cessation. Clin Pharmacol Ther 2006; 79: $600-8$.

84 Malaiyandi V, Lerman C, Benowitz NL, Jepson C, Patterson F, Tyndale RF. Impact of CYP2A6 genotype on pretreatment smoking behaviour and nicotine levels from and usage of nicotine replacement therapy. Mol Psychiatry 2006; 11: 400-9.

85 Sellers EM, Kaplan HL, Tyndale RF. Inhibition of cytochrome P450 2A6 increases nicotine's oral bioavailability and decreases smoking. Clin Pharmacol Ther 2000; 68: 35-43.

86 Gu DF, Hinks LJ, Morton NE, Day IN. The use of long PCR to confirm three common alleles at the CYP2A6 locus and the relationship between genotype and smoking habit. Ann Hum Genet 2000; 64: 383-90.

87 Youdim MB, Bakhle YS. Monoamine oxidase: isoforms and inhibitors in Parkinson's disease and depressive illness. Br J Pharmacol 2006; 147 Suppl 1: S287-96.

88 Fowler JS, Volkow ND, Wang GJ, Pappas N, Logan J, Shea C, et al. Brain monoamine oxidase A inhibition in cigarette smokers. Proc Natl Acad Sci U S A 1996; 93: 14065-9.

89 Gilbert DG, Zuo Y, Browning RA, Shaw TM, Rabinovich NE, Gilbert-Johnson AM, et al. Platelet monoamine oxidase B activity 
changes across 31 days of smoking abstinence. Nicotine Tob Res 2003; 5: 813-9.

90 Khalil AA, Steyn S, Castagnoli N Jr. Isolation and characterization of a monoamine oxidase inhibitor from tobacco leaves. Chem Res Toxicol 2000; 13: 31-5.

91 Lewis A, Miller JH, Lea RA. Monoamine oxidase and tobacco dependence. Neurotoxicology 2007; 28: 182-95.

92 Houtsmuller EJ, Thornton JA, Stitzer ML. Effects of selegiline (L-deprenyl) during smoking and short-term abstinence. Psychopharmacology (Berl) 2002; 163: 213-20.

93 George TP, O’Malley SS. Current pharmacological treatments for nicotine dependence. Trends Pharmacol Sci 2004; 25: 42-8.

94 Biberman R, Neumann R, Katzir I, Gerber Y. A randomized controlled trial of oral selegiline plus nicotine skin patch compared with placebo plus nicotine skin patch for smoking cessation. Addiction 2003; 98: 1403-7.

95 Schneider LS, Tariot PN, Goldstein B. Therapy with 1-deprenyl (selegiline) and relation to abuse liability. Clin Pharmacol Ther 1994; 56: 750-6.

96 Malin DH, Lake JR, Lin A, Saldana M, Balch L, Irvin ML, et al. Passive immunization against nicotine prevents nicotine alleviation of nicotine abstinence syndrome. Pharmacol Biochem Behav 2001; 68: 87-92.

97 Hieda Y, Keyler DE, Ennifar S, Fattom A, Pentel PR. Vaccination against nicotine during continued nicotine administration in rats: immunogenicity of the vaccine and effects on nicotine distribution to brain. Int J Immunopharmacol 2000; 22: 809-19.

98 LeSage MG, Keyler DE, Pentel PR. Current status of immunologic approaches to treating tobacco dependence: vaccines and nicotine-specific antibodies. Aaps J 2006; 8: E65-75.

99 Lindblom N, de Villiers SH, Kalayanov G, Gordon S, Johansson AM, Svensson TH. Active immunization against nicotine prevents reinstatement of nicotine-seeking behavior in rats. Respiration 2002; 69: 254-60.

100 Hatsukami DK, Kotlyar M, Allen S, Jensen J, Li S, Le C, et al. Effects of cigarette reduction on cardiovascular risk factors and subjective measures. Chest 2005; 128: 2528-37.

101 Koob GF, Bloom FE. Cellular and molecular mechanisms of drug dependence. Science 1988; 242: 715-23.

102 Wise RA. Forebrain substrates of reward and motivation. J Comp Neurol 2005; 493: 115-21.

103 Rothman RB, Glowa JR. A review of the effects of dopaminergic agents on humans, animals, and drug-seeking behavior, and its implications for medication development.Focus on GBR 12909. Mol Neurobiol 1995; 11: 1-19.

104 Platt DM, Rowlett JK, Spealman RD. Behavioral effects of cocaine and dopaminergic strategies for preclinical medication development. Psychopharmacology (Berl) 2002; 163: 265-82.

105 Gorelick DA, Gardner EL, Xi ZX. Agents in development for the management of cocaine abuse. Drugs 2004; 64: 1547-73.

106 Stanwood GD, Artymyshyn RP, Kung MP, Kung HF, Lucki I, McGonigle P. Quantitative autoradiographic mapping of rat brain dopamine D3 binding with [ $\left.{ }^{125} \mathrm{I}\right] 7-\mathrm{OH}-\mathrm{PIPAT}$ : evidence for the presence of $\mathrm{D} 3$ receptors on dopaminergic and nondopaminergic cell bodies and terminals. J Pharmacol Exp Ther 2000; 295: 1223-31.

107 Diaz J, Pilon C, Le Foll B, Gros C, Triller A, Schwartz JC, et al. Dopamine $\mathrm{D} 3$ receptors expressed by all mesencephalic dopamine neurons. J Neurosci 2000; 20: 8677-84.

108 Sokoloff P, Diaz J, Le Foll B, Guillin O, Leriche L, Bezard E, et al. The dopamine D3 receptor: a therapeutic target for the treatment of neuropsychiatric disorders. CNS Neurol Disord Drug Targets 2006; 5: 25-43.

109 Sokoloff P, Le Foll B, Perachon S, Bordet R, Ridray S, Schwartz JC. The dopamine D3 receptor and drug addiction. Neurotox Res 2001; 3: 433-41.

110 Levant B. The D3 dopamine receptor: neurobiology and potential clinical relevance. Pharmacol Rev 1997; 49: 231-52.

111 Le Foll B, Sokoloff P, Stark H, Goldberg SR. Dopamine D3 receptor ligands block nicotine-induced conditioned place preferences through a mechanism that does not involve discriminative-stimulus or antidepressant-like effects. Neuropsychopharmacology 2005; 30: 720-30.

112 Caine SB, Koob GF. Modulation of cocaine self-administration in the rat through D-3 dopamine receptors. Science 1993; 260: 1814-6.

113 Pilla M, Perachon S, Sautel F, Garrido F, Mann A, Wermuth CG, et al. Selective inhibition of cocaine-seeking behaviour by a partial dopamine D3 receptor agonist. Nature 1999; 400: 371-5.

114 Le Foll B, Schwartz JC, Sokoloff P. Disruption of nicotine conditioning by dopamine $\mathrm{D}(3)$ receptor ligands. Mol Psychiatry 2003; 8: 225-30.

115 Le Foll B, Frances H, Diaz J, Schwartz JC, Sokoloff P. Role of the dopamine D3 receptor in reactivity to cocaine-associated cues in mice. Eur J Neurosci 2002; 15: 2016-26.

116 Wood MD, Boyfield I, Nash DJ, Jewitt FR, Avenell KY, Riley GJ. Evidence for antagonist activity of the dopamine D3 receptor partial agonist, BP 897, at human dopamine D3 receptor. Eur J Pharmacol 2000; 407: 47-51.

117 Wicke K, Garcia-Ladona J. The dopamine D3 receptor partial agonist, BP 897 , is an antagonist at human dopamine D3 receptors and at rat somatodendritic dopamine D3 receptors. Eur J Pharmacol 2001; 424: 85-90.

118 Heidbreder CA, Gardner EL, Xi ZX, Thanos PK, Mugnaini M, Hagan JJ, et al. The role of central dopamine D3 receptors in drug addiction: a review of pharmacological evidence. Brain Res Brain Res Rev 2005; 49: 77-105.

119 Reavill C, Taylor SG, Wood MD, Ashmeade T, Austin NE, Avenell KY, et al. Pharmacological actions of a novel, high-affinity, and selective human dopamine $\mathrm{D}(3)$ receptor antagonist, SB277011-A. J Pharmacol Exp Ther 2000; 294: 1154-65.

120 Le Foll B, Goldberg SR, Sokoloff P. Dopamine D3 receptor ligands for the treatment of tobacco dependence. Expert Opin Investig Drugs 2007; 16: 45-57.

121 Heidbreder C. Selective antagonism at dopamine D3 receptors as a target for drug addiction pharmacotherapy: a review of preclinical evidence. CNS Neurol Disord Drug Targets 2008; 7: 410-21.

122 Andreoli M, Tessari M, Pilla M, Valerio E, Hagan JJ, Heidbreder CA. Selective antagonism at dopamine D3 receptors prevents nicotine-triggered relapse to nicotine-seeking behavior. Neuropsychopharmacology 2003; 28: 1272-80.

123 Ross JT, Corrigall WA, Heidbreder CA, LeSage MG. Effects of the selective dopamine D3 receptor antagonist SB-277011A on the reinforcing effects of nicotine as measured by a progressiveratio schedule in rats. Eur J Pharmacol 2007; 559: 173-9. 
124 Remington G, Kapur S. SB-277011 GlaxoSmithKline. Curr Opin Investig Drugs 2001; 2: 946-9.

125 Newman AH, Grundt P, Nader MA. Dopamine D3 receptor partial agonists and antagonists as potential drug abuse therapeutic agents. J Med Chem 2005; 48: 3663-79.

$126 \mathrm{Zhu}$ J, Reith ME. Role of the dopamine transporter in the action of psychostimulants, nicotine, and other drugs of abuse. CNS Neurol Disord Drug Targets 2008; 7: 393-409.

127 Hart C, Ksir C. Nicotine effects on dopamine clearance in rat nucleus accumbens. J Neurochem 1996; 66: 216-21.

128 Drew AE, Derbez AE, Werling LL. Nicotinic receptor-mediated regulation of dopamine transporter activity in rat prefrontal cortex. Synapse 2000; 38: 10-6.

129 Drew AE, Werling LL. Nicotinic receptor-mediated regulation of the dopamine transporter in rat prefrontocortical slices following chronic in vivo administration of nicotine. Schizophr Res 2003; 65: 47-55.

130 Miller DK, Sumithran SP, Dwoskin LP. Bupropion inhibits nicotine-evoked $\left[{ }^{3} \mathrm{H}\right]$ overflow from rat striatal slices preloaded with $\left[{ }^{3} \mathrm{H}\right]$ dopamine and from rat hippocampal slices preloaded with $\left[{ }^{3} \mathrm{H}\right]$ norepinephrine. J Pharmacol Exp Ther 2002; 302: 1113-22.

131 Covey LS, Glassman AH, Stetner F. Major depression following smoking cessation. Am J Psychiatry 1997; 154: 263-5.

132 Cryan JF, Bruijnzeel AW, Skjei KL, Markou A. Bupropion enhances brain reward function and reverses the affective and somatic aspects of nicotine withdrawal in the rat. Psychopharmacology (Berl) 2003; 168: 347-58.

133 Malin DH, Lake JR, Smith TD, Khambati HN, Meyers-Paal RL, Montellano AL, et al. Bupropion attenuates nicotine abstinence syndrome in the rat. Psychopharmacology (Berl) 2006; 184: 494-503.

134 Rauhut AS, Neugebauer N, Dwoskin LP, Bardo MT. Effect of bupropion on nicotine self-administration in rats. Psychopharmacology (Berl) 2003; 169: 1-9.

135 Hays JT, Dale LC, Hurt RD, Croghan IT. Trends in smokingrelated diseases. Why smoking cessation is still the best medicine. Postgrad Med 1998; 104: 56-62, 65-56, 71.

136 Gold PB, Rubey RN, Harvey RT. Naturalistic, self-assignment comparative trial of bupropion SR, a nicotine patch, or both for smoking cessation treatment in primary care. Am J Addict 2002; 11:315-31.

137 Shiffman S, Johnston JA, Khayrallah M, Elash CA, Gwaltney CJ, Paty JA, et al. The effect of bupropion on nicotine craving and withdrawal. Psychopharmacology (Berl) 2000; 148: 33-40.

138 Hughes JR, Stead LF, Lancaster T. Antidepressants for smoking cessation. Cochrane Database Syst Rev 2007; (1): CD000031.

139 Eisenberg MJ, Filion KB, Yavin D, Bélisle P, Mottillo S, Joseph L, et al. Pharmacotherapies for smoking cessation: a meta-analysis of randomized controlled trials. CMAJ 2008; 179: 135-44.

140 Kenny PJ, Paterson NE, Boutrel B, Semenova S, Harrison AA, Gasparini F, et al. Metabotropic glutamate 5 receptor antagonist MPEP decreased nicotine and cocaine self-administration but not nicotine and cocaine-induced facilitation of brain reward function in rats. Ann N Y Acad Sci 2003; 1003: 415-8.

141 Gass JT, Olive MF. Glutamatergic substrates of drug addiction and alcoholism. Biochem Pharmacol 2008; 75: 218-65.

142 Jones IW, Wonnacott S. Precise localization of alpha7 nicotinic acetylcholine receptors on glutamatergic axon terminals in the rat ventral tegmental area. J Neurosci 2004; 24: 11244-52.

143 Cadoni C, Di Chiara G. Differential changes in accumbens shell and core dopamine in behavioral sensitization to nicotine. Eur J Pharmacol 2000; 387: R23-5.

144 Booze RM, Welch MA, Wood ML, Billings KA, Apple SR, Mactutus CF. Behavioral sensitization following repeated intravenous nicotine administration: gender differences and gonadal hormones. Pharmacol Biochem Behav 1999; 64: 827-39.

145 Picciotto MR. Nicotine as a modulator of behavior: beyond the inverted U. Trends Pharmacol Sci 2003; 24: 493-9.

146 Liechti ME, Lhuillier L, Kaupmann K, Markou A. Metabotropic glutamate $2 / 3$ receptors in the ventral tegmental area and the nucleus accumbens shell are involved in behaviors relating to nicotine dependence. J Neurosci 2007; 27: 9077-85.

147 Liechti ME, Markou A. Metabotropic glutamate 2/3 receptor activation induced reward deficits but did not aggravate brain reward deficits associated with spontaneous nicotine withdrawal in rats. Biochem Pharmacol 2007; 74: 1299-1307.

148 Liechti ME, Markou A. Interactive effects of the mGlu5 receptor antagonist MPEP and the $\mathrm{mGlu2/3}$ receptor antagonist LY341495 on nicotine self-administration and reward deficits associated with nicotine withdrawal in rats. Eur J Pharmacol 2007; 554: 164-74.

149 Ferraguti F, Shigemoto R. Metabotropic glutamate receptors. Cell Tissue Res 2006; 326: 483-504.

150 Chiamulera C. Cue reactivity in nicotine and tobacco dependence: a "multiple-action" model of nicotine as a primary reinforcement and as an enhancer of the effects of smokingassociated stimuli. Brain Res Brain Res Rev 2005; 48: 74-97.

151 Paterson NE, Semenova S, Gasparini F, Markou A. The mGluR5 antagonist MPEP decreased nicotine self-administration in rats and mice. Psychopharmacology (Berl) 2003; 167: 257-64.

152 Tessari M, Pilla M, Andreoli M, Hutcheson DM, Heidbreder CA. Antagonism at metabotropic glutamate 5 receptors inhibits nicotine- and cocaine-taking behaviours and prevents nicotinetriggered relapse to nicotine-seeking. Eur J Pharmacol 2004; 499: 121-33.

153 Paterson NE, Markou A. The metabotropic glutamate receptor 5 antagonist MPEP decreased break points for nicotine, cocaine and food in rats. Psychopharmacology (Berl) 2005; 179: 255-61.

154 Bespalov AY, Dravolina OA, Sukhanov I, Zakharova E, Blokhina E, Zvartau E, et al. Metabotropic glutamate receptor (mGluR5) antagonist MPEP attenuated cue- and schedule-induced reinstatement of nicotine self-administration behavior in rats. Neuropharmacology 2005; 49 Suppl 1: 167-78.

155 McGeehan AJ, Janak PH, Olive MF. Effect of the mGluR5 antagonist 6-methyl-2-(phenylethynyl)pyridine (MPEP) on the acute locomotor stimulant properties of cocaine, $\mathrm{D}$-amphetamine, and the dopamine reuptake inhibitor GBR12909 in mice. Psychopharmacology (Berl) 2004; 174: 266-73.

156 Palmatier MI, Liu X, Donny EC, Caggiula AR, Sved AF. Metabotropic glutamate 5 receptor (mGluR5) antagonists decrease nicotine seeking, but do not affect the reinforcement enhancing effects of nicotine. Neuropsychopharmacology 2008; 33: 2139-47.

157 Kenny PJ, Chartoff E, Roberto M, Carlezon WA Jr, Markou A. NMDA receptors regulate nicotine-enhanced brain reward 
function and intravenous nicotine self-administration: role of the ventral tegmental area and central nucleus of the amygdala. Neuropsychopharmacology 2009; 34: 266-81.

158 Bormann J. Memantine is a potent blocker of N-methyl-Daspartate (NMDA) receptor channels. Eur J Pharmacol 1989; 166: 591-2.

159 Blokhina EA, Kashkin VA, Zvartau EE, Danysz W, Bespalov AY. Effects of nicotinic and NMDA receptor channel blockers on intravenous cocaine and nicotine self-administration in mice. Eur Neuropsychopharmacol 2005; 15: 219-25.

160 Thuerauf N, Lunkenheimer J, Lunkenheimer B, Sperling W, Bleich $\mathrm{S}$, Schlabeck M, et al. Memantine fails to facilitate partial cigarette deprivation in smokers--no role of Memantine in the treatment of nicotine dependency? J Neural Transm 2007; 114: 351-7.

161 Klitenick MA, DeWitte P, Kalivas PW. Regulation of somatodendritic dopamine release in the ventral tegmental area by opioids and GABA: an in vivo microdialysis study. J Neurosci 1992; 12: 2623-32.

162 Cubells JF, Blanchard JS, Smith DM, Makman MH. In vivo action of enzyme-activated irreversible inhibitors of glutamic acid decarboxylase and gamma-aminobutyric acid transaminase in retina vs brain. J Pharmacol Exp Ther 1986; 238: 508-14.

163 Dewey SL, Brodie JD, Gerasimov M, Horan B, Gardner EL, Ashby CR Jr. A pharmacologic strategy for the treatment of nicotine addiction. Synapse 1999; 31: 76-86.

164 Paterson NE, Markou A. Increased GABA neurotransmission via administration of gamma-vinyl GABA decreased nicotine selfadministration in the rat. Synapse 2002; 44: 252-3.

165 Dewey SL, Morgan AE, Ashby CR, Jr, Horan B, Kushner SA, Logan J, et al. A novel strategy for the treatment of cocaine addiction. Synapse 1998; 30: 119-29.

166 Brebner K, Childress AR, Roberts DC. A potential role for $\mathrm{GABA}(\mathrm{B})$ agonists in the treatment of psychostimulant addiction. Alcohol Alcohol 2002; 37: 478-84.

167 Fadda P, Scherma M, Fresu A, Collu M, Fratta W. Baclofen antagonizes nicotine-, cocaine-, and morphine-induced dopamine release in the nucleus accumbens of rat. Synapse 2003; 50: 1-6.

168 Shoaib M, Swanner LS, Beyer CE, Goldberg SR, Schindler CW. The GABAB agonist baclofen modifies cocaine self-administration in rats. Behav Pharmacol 1998; 9: 195-206.

169 Corrigall WA, Coen KM, Zhang J, Adamson KL. GABA mechanisms in the pedunculopontine tegmental nucleus influence particular aspects of nicotine self-administration selectively in the rat. Psychopharmacology (Berl) 2001; 158: 190-7.

170 Fattore L, Cossu G, Martellotta MC, Fratta W. Baclofen antagonizes intravenous self-administration of nicotine in mice and rats. Alcohol Alcohol 2002; 37: 495-8.

171 Paterson NE, Froestl W, Markou A. The GABAB receptor agonists baclofen and CGP44532 decreased nicotine selfadministration in the rat. Psychopharmacology (Berl) 2004; 172: 179-86.

172 Cousins MS, Stamat HM, de Wit H. Effects of a single dose of baclofen on self-reported subjective effects and tobacco smoking. Nicotine Tob Res 2001; 3: 123-9.

173 Cryan JF, Kelly PH, Chaperon F, Gentsch C, Mombereau $\mathrm{C}$, Lingenhoehl $\mathrm{K}$, et al. Behavioral characterization of the novel GABAB receptor-positive modulator GS39783 (N,N'dicyclopentyl-2-methylsulfanyl-5-nitro-pyrimidine-4,6-diamine): anxiolytic-like activity without side effects associated with baclofen or benzodiazepines. J Pharmacol Exp Ther 2004; 310: 952-63.

174 Macey DJ, Froestl W, Koob GF, Markou A. Both GABA(B) receptor agonist and antagonists decreased brain stimulation reward in the rat. Neuropharmacology 2001; 40: 676-85.

175 Urwyler S, Pozza MF, Lingenhoehl K, Mosbacher J, Lampert C, Froestl W, et al. N,N'-Dicyclopentyl-2-methylsulfanyl-5-nitropyrimidine-4,6-diamine (GS39783) and structurally related compounds: novel allosteric enhancers of gamma-aminobutyric acidB receptor function. J Pharmacol Exp Ther 2003; 307: 32230.

176 Guery S, Floersheim P, Kaupmann K, Froestl W. Syntheses and optimization of new GS39783 analogues as positive allosteric modulators of GABA B receptors. Bioorg Med Chem Lett 2007; 17: 6206-11.

177 Mombereau C, Lhuillier L, Kaupmann K, Cryan JF. GABAB receptor-positive modulation-induced blockade of the rewarding properties of nicotine is associated with a reduction in nucleus accumbens DeltaFosB accumulation. J Pharmacol Exp Ther 2007; 321: 172-7.

178 Paterson NE, Vlachou S, Guery S, Kaupmann K, Froestl W, Markou A. Positive modulation of GABA(B) receptors decreased nicotine self-administration and counteracted nicotine-induced enhancement of brain reward function in rats. J Pharmacol Exp Ther 2008; 326: 306-14.

179 Castane A, Berrendero F, Maldonado R. The role of the cannabinoid system in nicotine addiction. Pharmacol Biochem Behav 2005; 81: 381-6.

180 De Vries TJ, Schoffelmeer AN. Cannabinoid CB1 receptors control conditioned drug seeking. Trends Pharmacol Sci 2005; 26: 420-6.

181 Cohen C, Perrault G, Griebel G, Soubrie P. Nicotine-associated cues maintain nicotine-seeking behavior in rats several weeks after nicotine withdrawal: reversal by the cannabinoid (CB1) receptor antagonist, rimonabant (SR141716). Neuropsychopharmacology 2005; 30: 145-55.

182 Gonzalez S, Cascio MG, Fernandez-Ruiz J, Fezza F, Di Marzo V, Ramos JA. Changes in endocannabinoid contents in the brain of rats chronically exposed to nicotine, ethanol or cocaine. Brain Res 2002; 954: 73-81.

183 Castane A, Valjent E, Ledent C, Parmentier M, Maldonado R, Valverde $\mathrm{O}$. Lack of CB1 cannabinoid receptors modifies nicotine behavioural responses, but not nicotine abstinence. Neuropharmacology 2002; 43: 857-67.

184 Cossu G, Ledent C, Fattore L, Imperato A, Bohme GA, Parmentier $\mathrm{M}$, et al. Cannabinoid CB1 receptor knockout mice fail to self-administer morphine but not other drugs of abuse. Behav Brain Res 2001; 118: 61-5.

185 Cheer JF, Wassum KM, Sombers LA, Heien ML, Ariansen JL, Aragona BJ, et al. Phasic dopamine release evoked by abused substances requires cannabinoid receptor activation. J Neurosci 2007; 27: 791-5.

186 Le Foll B, Forget B, Aubin HJ, Goldberg SR. Blocking cannabinoid $\mathrm{CB} 1$ receptors for the treatment of nicotine dependence: insights from pre-clinical and clinical studies. Addict Biol 2008; 13: 239-52.

187 Rinaldi-Carmona M, Barth F, Congy C, Martinez S, Oustric D, 
Perio A, et al. SR147778 [5-(4-bromophenyl)-1-(2,4-dichlorophenyl)-4-ethyl-N-(1-piperidinyl)-1H-pyr azole-3-carboxamide], a new potent and selective antagonist of the CB1 cannabinoid receptor: biochemical and pharmacological characterization. J Pharmacol Exp Ther 2004; 310: 905-14.

188 Cohen C, Perrault G, Voltz C, Steinberg R, Soubrie P. SR141716, a central cannabinoid $(\mathrm{CB}(1))$ receptor antagonist, blocks the motivational and dopamine-releasing effects of nicotine in rats. Behav Pharmacol 2002; 13: 451-63.

189 Le Foll B, Goldberg SR. Rimonabant, a CB1 antagonist, blocks nicotine-conditioned place preferences. Neuroreport 2004; 15 : 2139-43.

190 Forget B, Hamon M, Thiebot MH. Cannabinoid CB1 receptors are involved in motivational effects of nicotine in rats. Psychopharmacology (Berl) 2005; 181: 722-34.

191 Rigotti NA, Gonzales D, Dale LC, Lawrence D, Chang Y. A randomized controlled trial of adding the nicotine patch to rimonabant for smoking cessation: efficacy, safety and weight gain. Addiction 2009; 104: 266-76.

192 Christensen R, Kristensen PK, Bartels EM, Bliddal H, Astrup AV. [A meta-analysis of the efficacy and safety of the anti-obesity agent Rimonabant]. Ugeskr Laeger 2007; 169: 4360-3.

193 Rucker D, Padwal R, Li SK, Curioni C, Lau DC. Long term pharmacotherapy for obesity and overweight: updated metaanalysis. BMJ 2007; 335: 1194-9.

194 Gatley SJ, Gifford AN, Volkow ND, Lan R, Makriyannis A. 123Ilabeled AM251: a radioiodinated ligand which binds in vivo to mouse brain cannabinoid CB1 receptors. Eur J Pharmacol 1996; 307: 331-8.

195 Gatley SJ, Lan R, Pyatt B, Gifford AN, Volkow ND, Makriyannis A. Binding of the non-classical cannabinoid CP 55,940, and the diarylpyrazole AM251 to rodent brain cannabinoid receptors. Life Sci 1997; 61(14): PL 191-7.

196 Bhatti AS, Aydin C, Oztan O, Ma Z, Hall P, Tao R, et al. Effects of a cannabinoid receptor (CB) 1 antagonist AM251 on behavioral sensitization to nicotine in a rat model of novelty-seeking behavior: correlation with hippocampal 5-HT. Psychopharmacology (Berl) 2009; 203: 23-32.

197 Shoaib M. The cannabinoid antagonist AM251 attenuates nicotine self-administration and nicotine-seeking behaviour in rats. Neuropharmacology 2008; 54: 438-44. 